Renewable Agriculture and

Food Systems

\section{cambridge.org/raf}

\section{US Farm Bill: Policy, Politics and Potential: Commentary}

Cite this article: Schaffer HD, Ray DE (2020). Agricultural supply management and farm policy. Renewable Agriculture and Food Systems 35, 453-462. https://doi.org/10.1017/ S1742170518000595

Received: 1 February 2018

Revised: 2 July 2018

Accepted: 7 November 2018

First published online: 9 January 2019

\section{Key words:}

Farm Bill; agricultural policy; supply management; farm policy; food policy; right to food; coerciveness; price elasticity; grain reserve; environmental acreage reduction

\section{Author for correspondence:}

Harwood D. Schaffer, E-mail: hdschaffer@utk. edu

\title{
Agricultural supply management and farm policy
}

Harwood D. Schaffer and Daryll E. Ray

Agricultural Policy Analysis Center, 1708 Capistrano Dr, Knoxville, TN 37922, USA

\section{Abstract}

For most economic goods market participants are 'not forced to make a deal.' They can walk away, perhaps permanently, or revisit a transaction later if the terms of trade are more to their liking. That is not the case for food. It is a biological necessity to participate in the food market. This coercive property of food demand and other unique market characteristics make the agricultural sector very unresponsive to changes in price and hence-in contrast to textbook expectations-its ability to quickly self-correct. In recent decades agricultural policy legislation has not taken into account the root causes of agriculture's chronic price and income problems. As a result, it has been largely ineffective and unnecessarily expensive. We argue in this paper that a well-designed supply management program can take agriculture's unique characteristics into account in a way that benefits farmers, consumers and the public as a whole.

\section{Why agricultural policy and farm bills?}

In making the case for reconsidering the implementation of agricultural supply management programs in the USA, this paper begins with a discussion of the ethical issues involved in the development of agricultural policy followed by an analysis of the economic characteristics of crop agriculture. The historic response to these concerns and the importance of food to the maintenance of stable societies has been the implementation of supply management programs. While supply management programs were used in earlier periods of US history, the modern use of them began as a part of the New Deal and continued in various forms until the adoption of the 1996 Farm Bill. The authors then look at various critiques that have been made concerning supply management programs including interference with farmer decision making, the capitalization of high loan rates into land and other fixed assets, the reduced competitiveness of US exports and the belief that government-held stocks overhung the market suppressing commodity prices. The paper concludes by describing a supply management program that has been developed by the Agricultural Policy Analysis Center and the Texas Farmers Union.

Before addressing the specific question of the particular agricultural policy that is the subject of this paper, it is necessary to step back and ask the question, 'why does any nation need a food and agricultural policy and more specifically, why does the USA need farm bills at all?' After all the USA does not have automobile legislative bills that need to be renewed and modified periodically. So, what is it about food and agricultural production that requires the repeated attention to the development of farm bills that is a part of the legislative landscape in the USA?

Food is treated differently by individuals and governments from other goods because unlike most other goods, food is a necessity for life. Together with air and water, food must be consumed on a regular basis or people die. Even though teenagers may think that they will die if they don't get the latest version of the 'Call of Duty' video game, 6 months from now they will still be alive even if they can't buy it. The same cannot be said for food. It must be obtained and consumed on a regular basis or life comes to a halt. When the price gets too high, short of malnutrition and starvation, people cannot drop out of the market and wait until some future time when new supplies come along and drive prices downward.

This paper is premised on the idea that given a choice surplus production of basic agricultural products is always preferable to famine. It is more ethical to hold stocks of basic agricultural products than it is to allow people to die from starvation. The world needs to have an agricultural system in which its productive capacity continuously and comfortably exceeds the amount of basic agricultural products needed to feed every man, woman and child. Farmers do not need to use all their productive capacity all the time, but it must be there both to respond both to a production shortfall and to an increasing world population.

While it is in the interest of human society, as a whole, to hold reserve stocks of basic agricultural products and to provide for the maintenance of a system of agricultural production that exceeds the immediate level of demand, it is not in the economic interest or capacity of any individual, farm operation or company to cover the costs of doing so. It is, however, in the interest of governments, particularly the governments of the most developed agricultural 
producing nations in the world, to adopt a coordinated set of policies to achieve these goals. Each nation and the world community has the responsibility to protect, respect and fulfill the Right to Food for every living human. 'The right to adequate food, like any other human right, imposes three types or levels of obligations on States parties: the obligations to respect, to protect and to fulfil. In turn, the obligation to fulfil incorporates both an obligation to facilitate and an obligation to provide' (CECSR, 1999, 4). This paper understands the responsibility to fulfill as including the maintenance of a system of agricultural production that exceeds the immediate level of demand as well as meets the immediate level of nutritional demand.

\section{The economic characteristics of agricultural production}

The nature of food as a necessity for life introduces coerciveness into the demand side of the economic equation (Schaffer, 2010). Unlike the ideal exchange between a buyer and a seller in which either can walk away with no or minimal consequences, in the case of food if the two cannot agree on a price, the buyer cannot wait until the product is available at a price they can afford. Humans need an adequate and nutritious supply of food on a regular basis and if they cannot obtain it there are serious consequences for their health and life. This coerciveness affects the economic characteristics of the aggregate demand for food.

After basic nutritional levels are met, consumers do not respond to price declines by expanding overall food consumption. With low prices people may introduce meat into a grain-based diet and they move from buying hamburger to purchasing a steak now and then. In the face of higher prices, they move in the opposite direction, but people consume about the same number of calories over a wide range in prices.

With most consumer goods, drop the price and the market clears. Go into a store the day after Christmas and people are pawing through the ornaments, lights and wreaths because the price is discounted by 50 percent or more. In a few days, the market has cleared and manufacturers and retailers are busy making plans for the next year. Drop the price of cars at the end of a model year and the unsold vehicles are quickly snapped up as the new cars arrive on the lot at the full price. In case of food, the small increase in demand in response to low prices is not sufficient for the market to clear to the point that prices increase sufficiently to cover the cost of production. Economists call this the low price-elasticity of demand.

There is also a price responsiveness problem on the supply side. In the short- to medium-run farmers do not respond to lower prices by voluntarily taking acres out of production and waiting for profitable price return. In fact, in the face of lower prices, farmers have every incentive to maximize their production per acre so that they can spread their fixed costs out over more bushels, bales or hundredweight. They certainly are not going to reduce production per acre on land rented for a pre-specified, fixed fee. There are a couple of reasons for this. Farmers are reluctant to give up rented ground during a low-price period because they will never get that acreage back when prices are profitable. As long as farmers have the expectation that the price will be above the variable cost of production, the income from the rented acres can be applied to total fixed costs, reducing total losses. Hence total agricultural production declines little even when prices decline sharply. They may switch crops in an attempt to increase net revenue, but they, or better-financed neighbors, will plant all of their cropland to something in the short- to medium-run. This characteristic is what economists call a low price-elasticity of total agricultural crop supply.

If there were sufficient responsiveness to lower prices on the part of either consumers or farmers, the chronic price/income problems that face crop agriculture would not exist and there would be no need for farm programs as we know them. But with minimal price responsiveness in the short- to medium-run on both the demand and supply sides of major crops, farmers experience long periods of low prices punctuated by short periods of high prices. The short periods of higher prices are usually the result of either weather or disease-caused production problem. In addition, there have been four longer periods of high prices over the last century: World War I, World War II (WWII), the decision of the Soviet Union to import grain in response to a crop production shortfall instead of reducing their cattle herd in the early 1970s followed by a brief period of exports to developing countries funded by oil-rich countries seeking a place to invest their petro-dollars and the recent ethanol boom. Each of these cases is the result of governmental decisions-not the normal functioning of aggregate agricultural commodity markets-and was followed by an extended period of low prices.

But the low price-elasticity on both the demand and supply side is not the only issue that affects the economic flexibility of crop agriculture when compared to the typical firm that forms the basis of analysis in economic textbooks. The price of the dominant crop in the USA is determined not by the market clearing price-as textbook graphs assert-but rather by the year-ending stocks-to-use ratio. The stocks-to-use ratio for a given crop is the ratio of the supply of that crop that is unsold at the end of the crop-year ${ }^{1}$ (also called carry over) divided by the production of that crop in that year. With a production item like food crops, it is important to society that the market does not clear. There is a value in having surpluses to provide protection in the case of a shortfall in production in any given year but the greater the surplus the lower the price.

In the USA, the key price determinant is the stocks-to-use ratio for corn, the dominant crop. While competing crops vary from one region of the USA to another, cotton and peanuts in the South, winter wheat in the Midwest, spring wheat, barley, dried beans, canola and hops along the Canadian border, and soybeans everywhere they compete with corn for acreage. If supply or demand conditions cause the price of a competing crop to sharply increase (decrease) compared to price of say corn, land will move toward (away from) the competing crop and away from (toward) corn. Farmers use these price signals ${ }^{2}$ in conjunction with agronomic constraints to make individual decisions in the allocation of their acreage to various potential crops. In the USA, the price level of corn in the USA sets the relative price of other crops depending on their need to increase or decrease planted acres. Thus, if there is a low-price problem with the dominant crop, the low prices spread to the other crops as well.

In planting, farmers are managing a biological process that does not allow them to control their production level in the same way that other industries control their production. When

\footnotetext{
${ }^{1}$ A crop-year (also called a crop marketing year) runs from the nominal beginning of the harvest of a crop in the major crop producing region in a given year until the nominal beginning of the harvest in the following year. In the USA, crop-years for various crops are defined by the United States Department of Agriculture, https://www.ers.usda.gov/ data-products/feed-grains-database/documentation/\#myears.

${ }^{2}$ Farmers generally use the price at the local grain elevator which in turn is based on the price on the dominant board of trade for that crop, adjusted for local elevator handling costs and transportation costs to a delivery point.
} 
farmers put the seed in the ground they do not know if they are going to have a bumper crop or a crop failure. They can do little to affect the final level of production mid-season other than treat a disease or a pest that may appear. Other industries can idle a production shift in response to slack demand and bring it back into production when demand increases. But farmers have a short period of time in which they can implement production decisions and cannot adjust production levels later in the year in response to shifts in demand.

In designing agricultural policy instruments, policy makers need to keep these issues in mind and if they miss something, their policy will have unintended consequences. The argument being made by this paper is that an agricultural policy based on implementing a well-designed supply management can take these characteristics into account in a way that benefits farmers, consumers and the public as a whole.

The translation of cuneiform tablets and the excavation of grain storehouses in the Fertile Crescent show that the management of the supply of grain was essential to the success of those societies three and four millennia ago. Joseph is said to have told the Pharaoh about 7 fat years and 7 lean years and the need to store grain during the fat years.

As early as the first century B.C., the Chinese leader Li K'o recognized this problem and developed a government-held granary to provide fair prices to farmers in years of abundant production and make grain available to consumers in years of crop failure. Li K'o recognized that public policy needs to provide a mechanism that would balance supply and demand in a way that benefited both farmers and consumers. The Chinese have continued to use this system in various forms to this day. The earliest use of supply management policies in the USA can be traced to the late 17th century as several of the colonies sought to control the production of tobacco in response to plummeting prices. With the financial trauma of the Great Depression, supply management policies became the central element of US farm programs in the 1930s. In various forms these policies continued until they were eliminated with the adoption of the 1996 Farm Bill.

While a full discussion of the shift away from supply management policies that support price to policies that support farm income is beyond the scope of this paper, it can be said that this policy change reflects an economy wide shift from the demand-side Keynesian economic policies of the New Deal to the supply side neoliberal economic policies in vogue since the Reagan-Thatcher era in the 1980s.

A supply management program protects farmers from extended periods of low prices through the establishment of a loan rate and reserve program. With a supply of reserve stocks and a release price, the supply management program protects consumers from extremely high prices and assures the market of a reliable supply of essential storable farm commodities.

In a supply management program, the government establishes a non-recourse loan rate (also called a marketing loan rate) for each of these commodities and takes off the market the quantity of those commodities that is sufficient to achieve the established minimum price level. This process serves to establish a floor price for each commodity. When the USA previously used a supply management program, the season average price for the various commodities generally remained at least 10 percent above the loan rate. Commodity prices rise and fall in response to the net effect of changes or anticipated changes in production and utilization.
The amount of the commodity taken off the market is held in a reserve until the market price reaches a specified release price level. This happens in response to either a production shortfall like we saw in 2012 in corn or a sudden increase in demand like the entry of the Soviet Union into international grain markets in the early 1970s.

Once the market price of a commodity reaches the release price, reserve commodities are sold to prevent the price from going any higher. With the sale of reserve stocks, the government recovers all or most the cost of acquisition of the stored commodities, reducing the cost of operating the program. It is possible that stocks would have to be held for a decade or more before there would be an event that would trigger the release of a commodity into commercial market channels.

If the reserve takes in the allocated amount of a commodity and the price remains low, the government institutes an acreage reduction program as a means of reducing production to more closely mirror current demand.

By setting a floor price, a supply management program corrects for the low price-elasticity of demand by taking excess supply out of the commercial marketplace and holding it in a reserve. At harvest, farmers can take out a low interest 9-month marketing loan with the US government. Farmer can use this money to pay off costs incurred in the production of the crop and hold the crops in hopes of obtaining a price that is higher than the usual harvesttime lows. If at the maturity of the loan or any time earlier at the discretion of the farmer, the market price less the accrued interest is less than the loan the farmer can forfeit the crop to the government as full payment of the loan. The US government then holds these crops through an entity called the Commodity Credit Corporation (CCC) and pays a storage fee to a bonded warehouse. Placing excess stocks in government storage compensates for the low price-elasticity of supply by reducing the supply of agricultural commodities available to the commercial market place, keeping the price at or above the loan rate. ${ }^{3}$

Likewise, by instituting an acreage reduction program a supply management program corrects for the low price-elasticity of supply. While, in the short- to medium-run, farmers do not reduce their planted acreage in response to low prices, once the reserve reaches the optimum level, the government can do for farmers what is not in the self-interest of any single farmer to do, reduce the number of planted acres in response to continued low prices, thus compensating for the low price-elasticity of supply. While there is no general agreement on the optimum level for the reserve of each crop, the authors would argue that it should be sufficient to provide a supply of the crop in question in the event of a 25 percent shortfall in production from the previous year plus half that amount if the disruption goes into a second year. A reserve of this size would provide a degree of stability to the market in the event of a shortfall in production or an unexpected increase in demand.

In both the cases of a reserve and an acreage reduction program, less output is on the market when prices are 'low.' One

\footnotetext{
${ }^{3}$ The Marketing Assistance Loan program was first instituted with the adoption of the Agricultural Adjustment Act of 1938 and has remained in effect through the 2014 Farm Bill. Beginning with the 1996 Farm Bill (the 1985 Farm Bill for cotton), farmers were not required to forfeit their crop in payment of the loan but could retain ownership. The difference between a price below the loan rate and the loan rate is called a marketing loan gain (MLG). Farmers who do not take out a marketing loan can make this same gain by claiming a loan deficiency payment (LDP) based on the Posted County Price on a day of the farmer's choosing within the relevant 9-month period. In general parlance both payments have been referred to as LDPs.
} 
of the advantages of a supply management program when compared to Agricultural Risk Coverage, Price Loss Coverage, Loan Deficiency Payments and other counter-cyclical programs is that it only pays for the bushels, bales and hundredweight of agricultural commodities that it takes off the market. These other programs can end up making a payment on every bushel, bale and hundredweight produced.

By acknowledging the price responsiveness characteristics of aggregate agriculture, judicious government policies can create a price band within which agricultural commodity markets efficiently respond to market signals.

\section{Critiques of earlier supply management programs}

Supply management programs have been criticized for a number of reasons that need to be addressed. ${ }^{4}$ Among the critics are Luther Tweeten who wrote, 'Alleviating financial stress in farming by increasing supports under commodity programs... is the least economically desirable of the policy options...' (Tweeten, 1985, 83-112). Brian D. Wright argues that with 'the development of futures markets and options...governmental market stabilization to protect producers against short-term commodity-specific price risks is becoming increasingly redundant. If short-term hedging services are left to the private market, acreage restrictions can provide a reserve of protection for producers in case low producer prices persist over several seasons, but they should be used sparingly. No other direct commodity-specific price interventions are justified in the long-run, but if they cannot be avoided, deficiency payments are preferable to price support loans...' (Wright, 1985, 257-276). In his 2001 statement to the House of Representatives Committee on Agriculture, Bruce L. Gardner said, 'I believe that our commodity programs on the whole are now an improvement over those that preceded the FAIR Act [1996 Farm Bill] in that they do not attempt to micromanage commodity markets or farmers' decisions as much as former programs have done' (US, 2001, 46-49).

It has been argued that supply management programs have interfered with crop production decisions. This issue comes to the fore when there is a change in the relative demand among the various storable crops. Because of the demand for soybeans as a source of protein meal to be used as cattle feed in the USA and elsewhere, additional soybean acreage was needed. But farmers had an incentive to maintain their corn base acres to maximize their potential for farm program payments-at that time soybeans were not a program crop. The result was that the shift of additional acres from other crops into soybeans was slower than was indicated by market signals.

An important change included in the 1996 Farm Bill was the shift from managing acreage crop by crop to allowing for planting flexibility. With planting flexibility, farmers gained the ability to adjust their production decisions based on agronomic limitations and market signals rather than program conditions. Planting flexibility needs to be a part of any supply management program. Schaffer et al. used the POLYSYS modeling system to conduct a study for the National Farmers Union in 2012 that allowed for planting flexibility (Schaffer, 2012). In this study, US corn acreage increased relative to other crops in response to the adoption of the

\footnotetext{
${ }^{4}$ Two books, 'The Making of the 1996 Farm Act,' Lyle P. Schertz and Otto C. Doering III and 'U.S. Agricultural Policy: The 1985 Farm Legislation,' edited by Bruce L. Gardner, provide context to the many critiques of supply management programs that led to their elimination in the 1996 Farm Bill.
}

Renewable Fuels Standard (RFS) which required the blending of corn-based ethanol into the US gasoline supply at a 10 percent rate.

Policymakers like Schnittker $(1985,203)$ have argued against supply management programs especially when they guarantee loan rates close to the full cost of production which, in turn, get capitalized into fixed resources like land. To some extent, that is true. In particular, the most efficient farmers would benefit from a loan rate that is near their long-term cost of production. Any profit that they make above household expenses could then be used to purchase extra land at prices that could not be matched by farmers whose long-term costs were higher. But that is always true and is not the unique result of a supply management program.

For many farming operations it does not matter where the extra money comes from, it will be capitalized into land. Whether the extra money comes from direct decoupled payments, counter-cyclical payment (CCP) programs, an inheritance, or revenue insurance, a portion of it will be capitalized into land, resulting in higher land costs.

If a farmer and/or spouse works in town that extra income is likely to result in higher land prices, not because that farmer will use it to purchase more land, but rather because they are able to keep farming and thus keep their land from coming on the market, thereby putting an upward pressure on land prices.

But compared to the way the revenue insurance program operated when prices were high, supply management programs have a very small impact on land prices. The price component of revenue insurance is determined by the USDA using the harvest-time futures price in the period before the crop is normally planted. While the marketing loan rate is set in law at a price that is below the full cost of production, the price guarantee in the revenue insurance program can be well above the full cost of production. By guaranteeing revenue that is well above the full cost of production, as was the case in numerous years between 2007 and 2013, subsidized revenue insurance provided farmers with the wherewithal to drive up land prices and land rental rates, increasing production costs for nearly all producers.

If a supply management program had been in force in the late 1990s, farmers would not have had the incentive to lobby so hard for programs and policies to set blend requirements for mixing ethanol into the national gasoline supply. In the absence of ethanol blend requirements and subsidized crop insurance, it is not hard to make the case that the increase in land prices would not have been anything like what we have seen over the last decade. Much of the crop insurance subsidy was capitalized into land at a level far above what would have happened with a supply management program.

People who do not like crop supply management programs sometimes argue that these programs put a cap on exports, particularly corn exports and especially if loan rates are near the full cost of production. They argue that when the USA implements a reduction in acreage to keep reserve stocks from getting too large, foreign export competitors take that as a signal and increase their acreage, capturing exports that should have accrued to the USA.

In 1979 and 1980 US corn exports exceeded 2 billion bushels for the first time. The 1985 Farm Bill was designed to bolster US exports by reducing the loan rate. The 1996 Farm Bill eliminated the last vestige of supply management. And still, in the 36 intervening years (1981 through 2016 crop years), US corn exports reached the 2-billion-bushel level only eight times. Non-US 
corn exports exceeded 3 billion bushels in each of the last 6 crop years. Total corn exports from non-US countries have exceeded US corn exports over the last 20 years, while in 1979 non-US corn exports were 16 percent of those of the USA.

It can be argued that this does not account for the corn that is exported in the form of beef, pork and poultry. And that is true. The corn embodied in net meat exports is important, but even with increasing net meat exports total feed demand has remained flat at an average of 5.4 billion bushels per year over the last 20 years. Increased corn exports embodied in meat has not been sufficient to keep year-ending corn stocks from increasing since the end of the ethanol boom.

Looking at ethanol, the USA shifted from being a net importer of ethanol to a net exporter in 2010. Net exports of ethanol have averaged 15.5 million barrels for the last 7 years. But, as important as they are, net meat, and ethanol exports have not been sufficient to keep year-ending corn stocks from increasing in recent years.

The principal signal that brings extra acreage into production is not a policy that sets the loan rate near the full cost of production, but rather one that allows the price to get well above the full cost of production. Those higher prices catch the attention of farmers worldwide and the extra acreage that comes into production is slow to be taken out of production, even with an extended period of low prices; we are talking about decades not years.

Whether the USA uses a program that depends on crop price supports (supply management in the pre-1996 era) or one that uses programs that support total farm revenue (1997 to the present), the impact of changing US agricultural policy on corn exports is negligible.

So, what is going on? First, farmers elsewhere in the world are no different from farmers in the USA; they want to feed their own people. The result is that world corn exports have declined as a percent of world production (16.2 percent for 1974-1983 crop marketing years to 12.4 percent for 2007-2016 crop marketing years).

Secondly, even when the world percentage of production that is exported has increased as is the case for barley, soybeans, rice, and wheat, the US share of world exports has declined. The USA has a mature agricultural economy while many other countries are playing catch-up, both in terms of technology and acreage.

Because of the strength of the US agricultural sector, with its ability to produce crops in excess of domestic demand, and the hegemonic role the USA has played in the world since WWII, the USA has become both the oligopoly price leader and the residual supplier ${ }^{5}$. Basic agricultural commodities around the world, with a few exceptions, are priced off US markets taking into consideration shipping costs to any given location. To make an export sale, all other countries need to do is offer a delivered price that is slightly lower than the US delivered price, taking into account any variation in quality. If the price in the US declines, the price elsewhere declines as well.

For many crops and their substitutes, the US price is the de facto world price. The policy by which the 1985 Farm Bill allowed the loan rate to be lowered in attempt to allow the USA to get its

\footnotetext{
${ }^{5}$ The crop export market is oligopolistic because for each crop and its substitutes there is a limited number of countries that, taken together, account for most of the world's exports. In an oligopolistic market, whether it is countries or companies, market participants sooner or later fall into a follow-the-leader pattern when it comes to price. Those who follow make their sales at prices that are slightly below the price offered by the price leader and clear their markets leaving the remaining sales to the price leader. In this case the oligopoly price leader is also the residual supplier.
}

price down to the world price was an exercise in futility; US exports were unaffected by the policy change. Because of its dominance in the market and its ability to produce and store agricultural crops, the USA is the world's residual supplier. Most countries only purchase from the USA when their local production is inadequate and the US's export competitors have little or nothing to sell.

Whether the US farm program utilizes a price support mechanism-with either high or low loan rates-or a farm revenue support mechanism makes little difference on US crop exports. Either way, the USA remains the oligopoly price leader and residual supplier for basic storable farm commodities.

Farmers often complained about supply management programs because in their view the floor price, established by the loan rate, became a ceiling price as well, cutting of much of a chance to enjoy a year or two of profitability. When the loan rate and the release price are set too close together, that is true. The solution is not to stop setting a reasonable loan rate, but rather to set a release price high enough to allow the market to work without bringing unnecessary land into production.

Farmers also have complained that reserve stocks overhang the market and depress the price of their production. That is true when the reserve price is too close to the loan rate so there is little gain to be had in the market before reserve stocks are released. But, what farmers don't recognize is that when the government does not operate a stock-holding reserve program any excess carryover beyond pipeline needs remains in the commercial market directly overhanging the price. Ironically the overhanging stocks are mostly those in farmers' own bins. When the USA operated a farmer-owned reserve (FOR), the USDA reduced release prices in response to pressure from farmers. When the market would get within a few cents of the release price and then decline, farmers would complain to their members of Congress that they could have made a profit if the USDA had allowed them to sell the crop they held in the FOR at the peak. The members would then pressure the USDA to reduce the release price to just below the previous peak. Successive repetitions of this process ultimately made the FOR ineffective. By way of contrast, when the crop was held by the CCC and the price reached within half a cent of the release price, neither the government nor farmers complained.

Another issue is the argument that reserve stocks substitute for commercial stocks. Again, there is some truth to that complaint. For example, if commercial year ending stocks of corn are at 2.1 billion bushels in the absence of a reserve program and a reserve program is put in place commercial stocks will drop to 1 billion bushels or a little less and reserve stocks will be 1.1 billion bushels. So where did those 1.1 billion bushels come from? For the most part those 1.1 billion bushels were being held in on-farm storage bins. They are the bushels that farmers were unable or unwilling to sell, hoping for a higher price. With a marketing loan program that has a loan rate at 95 percent of the cost of production, most of those bushels would have been under loan and then forfeited to pay off the Marketing Loan. For the most part, grain elevators and end users do not hold any more than the comfortable stock levels they generally operate with (what is referred to as pipeline supplies). The bulk of the carryover stocks are held unsold by farmers.

The last objection is the classic libertarian argument that stock holding is not an appropriate function for governments. At that point, the argument becomes philosophical and no amount of data will resolve the difference between those who believe stock 
holding is a legitimate function of government and the libertarians who believe it is not. In either case the critical word is 'believe.'

\section{A supply management program for a new millennium}

The USA instituted a non-recourse marketing loan program in 1938 to enable farmers to avoid having to sell their crop at harvest time, a time when prices are usually at their annual low. Instead of selling their crop, farmers can take out a 9-month, low-interest loan with the government. Farmers often use the loan to pay off production expenses, but there are no conditions on how they can use the loan.

The farmer can then wait for higher prices before paying off the marketing loan plus the accrued interest. This marketing loan (or non-recourse loan) has allowed farmers to engage in the orderly marketing of their crop at prices that are usually higher than those available at harvest. In the case where the market value of the crop at the end of 9 months does not exceed the value of the loan plus accrued interest, the farmer can forfeit the crop to the government as full payment of the loan. The farmer does not have to make up any shortfall in the value of the crop at the time of forfeiture; the government does not have recourse to any of the farmer's other assets to pay off the differencethus the term non-recourse loan.

Following the adoption of the 1996 Farm Bill, US farm policy abandoned the stockholding role of the marketing loan program as a means of stabilizing commodity prices and thus the crop portion of net farm income. This change was made because policymakers in and out of Congress believed that agriculture was more price responsive on the supply side as the result of the switch from farm produced inputs (manure for fertilizer, saved seeds and family labor in weeding) to purchased inputs. Because they believed that farmers would reduce total planted acreage in response to low prices, Congress took the money that would have been used to maintain supply management programs and converted it to direct decoupled payments that were to transition to $\$ 0$ over a period of years.

The anticipated self-adjustment in the amount of land used for crop production in response to low prices did not occur. The cost of the Marketing Loan Gain/Loan Deficiency Payment program began to skyrocket. By 1998, Congress also voted to provide farmers with Emergency Payments to enable them to stave off bankruptcy. These payments continued through the 2001 crop year when Congress replaced the 1996 Farm Bill a year early with the 2002 Farm Bill. While farm legislation since the Agricultural Adjustment Act of 1938 sought to stabilize prices as a means of supporting farm income, beginning with the 2002 Farm Bill, legislators sought to stabilize revenue as a means of stabilizing farm income. To achieve this goal of stabilizing revenue, Congress converted the Emergency Payments into fixed decoupled payments that amounted to more than $\$ 5$ billion a year-these payments continued through the 2008 Farm Bill but were discontinued in 2014. In addition, Congress provided a significant subsidy to the crop insurance industry in order to provide farmers with subsidized crop revenue insurance that would provide farmers with a payment when the revenue per acre in the fall was below the anticipated revenue per acre just before planting time.

The strategy of revenue stabilization would have been a failure from the beginning if farmers had not been able to effectively promote ethanol as a fuel oxygenate as well as a means of ensuring the country with a domestic supply of transportation fuel. This lobbying by farmers included the period in which weather disrupted oil supplies from the Gulf of Mexico and a war in the Middle East made imported oil from an unstable region a risky bet. When the price of gasoline shot from the $\$ 2.00$ range to above $\$ 4.00$ per gallon in a short period of time, Congress, with the support of the George W. Bush administration, adopted the RFS which would result in a significant increase in the amount of corn needed to produce ethanol that would be blended into the domestic automobile fuel supply.

As a result of the RFS and the investment in ethanol plants by farmers and non-farm capital investment, the demand for corn for these ethanol plants began to increase by some 500 million bushels a year over the 10-billion-bushel base demand for cattle feed, exports and corn refining. The scramble for additional acreage to accommodate this increase in corn demand sent the price of most crops to levels well above the full cost of production. With anticipated revenue per acre well above the full cost of production the strategy of revenue stabilization worked well, though the price tag was significantly higher than previous farm programs.

The continuous increase in the demand for corn along with a significant crop failure in 2012 kept the price of corn and thus most other crops well above the full cost of production until 2013 when the demand for corn for ethanol production leveled off. With supply outrunning demand commodity priced began to tumble. With harvest-time prices significantly below the full cost of production, crop revenue insurance stabilized crop revenue per acre at levels that did not cover farmers' costs. Between 2013 and 2017, net farm income declined by 50 percent. Excluding livestock production, net farm income from crops was negative with little hope for positive numbers on the horizon.

The return of an extended period of low prices and the failure of the revenue stabilization strategy confirmed the long-held view of the Agricultural Policy Analysis Center ${ }^{6}$ (APAC) and the Texas Farmers Union (TFU) that the economics of crop agriculture is characterized by the low-price-elasticity of both supply and demand. As a result, these groups believe that the price stabilization mechanism of a well-designed supply management needs to be a key component of US farm commodity policy.

A marketing loan program is at the center of the supply management program that APAC developed under a grant from the TFU. The key to the role the marketing loan program plays in the proposed program is the level at which the loan rate is set. The goal is to set the loan rate at a level where there is no need for additional or supplemental programs.

In the past, when the loan rate was set well below the full cost of production, Congress had to establish a supplemental CCP program to provide the level of net farm income necessary to maintain a robust crop agricultural sector.

It makes little sense to develop a secondary program to make up for the deficiencies of the primary commodity program, whether the primary program is the historic supply management program, the unencumbered free market program that resulted from the adoption of the 1996 Farm Bill, or the current revenue insurance program.

\footnotetext{
${ }^{6}$ The Agricultural Policy Analysis Center (APAC) was established by Daryll E. Ray in the mid-1990s as part of his work as the Blasingame Chair of Excellence in the Agricultural Economics Department at the University of Tennessee, Knoxville. With his retirement from the University of Tennessee and that of Harwood D. Schaffer, APAC was reconstituted as an independent analytical organization devoted to providing information that meets the needs of farmers and consumers.
} 
Our challenge to Congress is to develop a program that gets the policies right in the first place so there is no need for CCPs, emergency payments, loan deficiency payments or payments under either the current Agricultural Risk Coverage or the Price Loss Coverage programs, all elements of a low-price policy. The beneficiaries of subsidized low-price policies are those industries that use raw agricultural commodities to feed their animals or make their processed food products. Input industries-seeds, fertilizers, pesticides and herbicides-oppose the acreage reduction component of supply management programs.

In the APAC/TFU proposal, the loan rate for corn is set at 95 percent of the Olympic average ${ }^{7}$ of the national full cost of production for the prior five years. History indicates that once the marginal over-supply is taken off the market the minimum season average price paid to farmers for their corn is generally at least 10 percent above the loan rate.

Because corn is the dominant crop in the USA, the loan rates for other crops are set at their historic ratio to corn. Over the last decade the corn-to-soybeans ratio of the season average prices paid to farmers was 2.5 to 1 (2.5:1); for wheat, the ratio was $1.44: 1^{8}$. The loan rate for all covered crops was set to their historic ratio. The one crop for which the APAC modeling does not use the historic ratio is grain sorghum. The corn to grain sorghum ratio was set at 1:1 to encourage the raising of dryland grain sorghum instead of irrigated corn over the Oglala Aquifer, slowing the depletion of that important aquifer.

By using the historic ratios, the loan rates do not skew the planting decisions of farmers. For instance, when the corn-tosoybean ratio increases to $2.8: 1$, some farmers will reduce their acreage of other crops to produce more soybeans. Similarly, if the soybean-to-corn ratio drops to 2.2:1, farmers will move acreage out of soybeans and into another crop, increasing total corn acres. By using the historic ratios, the APAC/TFU supply management program allows for planting flexibility rather than crop by crop interventions.

The commodities that are forfeited to the government under the marketing loan program are held by the government until they are needed by the market because of a production shortfall or an unanticipated increase in demand. The price at which agricultural commodities are sold into the open market is called the release price. In the model, the release price was set at 1.75 times the loan rate but should not be so high to encourage a sudden increase in the amount of land devoted to agricultural production. The impact of the release price on the conversion of conservation and pasture land to cropland needs to be monitored and adjusted if needed. Historically, the release price has been triggered for less than a year before returning with the promise of the return of trend-line production in the following year.

Establishing a wide price band allows the market to work relatively efficiently in guiding farmer planting decisions and allocating the available supply among competing uses. At the one end, the loan rate protects farmers from long periods of low prices and at the other the release price sets an upper bound, protecting consumers.

\footnotetext{
${ }^{7}$ The Olympic average used in US agricultural policy is the average over a 5-year period, excluding both the high and the low years.

${ }^{8}$ These historic ratios are the ones that production economists have used for the last quarter century. As part of the APAC/TFU study, these ratios were reviewed using a weighted average of prices over the last decade and have not changed despite changes in production costs and yields. These ratios need to be checked as a part of the development of subsequent farm bills.
}

As can be seen during the 2007-2012 period, an extended period of prices well above the full cost of production is not in the best interests of farmers because those prices bring additional resources (land in the USA and around the world) into production which results in an extended period of low prices, as has been seen over the past 4 years.

If the marketing loan rates are used to take storable agricultural commodities off the market and set a floor on crop prices, what happens to the commodities that are forfeited to the government as full repayment of the loan?

Originally storable commodities received as repayment for government marketing loans were held by the CCC, a US government owned and operated entity that was created to stabilize, support and protect farm income and prices. When the market price of a given commodity reached the release price, the government stocks of that commodity would be sold until the price fell back below the release price. The government would profit from the difference between the loan rate and the release price minus accrued storage costs. This net profit would reimburse the government for the cost the acquisition of the stored crop, reducing the overall cost of the program. Given the drought resistance that is being bred into conventional crops, production shortfalls sufficient to trigger a price above the release price might occur fewer than 1 year in ten.

In later years, farmers argued that they should be able to profit from the increase in price, so Congress established a FOR which paid farmers to hold stocks of grain in reserve to regulate the amount of grain commercially available and thereby stabilize prices. Farmers were paid for storing the grain and could sell it when the price reached a pre-determined level, pay off the loan plus accrued interest, and benefit from the increase in price above the loan rate. Over time, the price band between the loan rate and the release price was narrowed, limiting the effectiveness of the program.

With CCC storage, Congress is not under pressure from farmers to reduce the release price when the market price gets close to but does not exceed the release price as it was with the FOR. For this reason, the APAC/TFU supply management program uses the CCC to hold the commodities forfeited as full repayment of the Marketing Loans taken out by farmers.

The crops in CCC storage serve as a reserve that can be tapped in the case either of a production shortfall or an increase in demand that raises the market price above the release price. How large the reserve should be and what happens to the program when the cap is reached are two important questions for any supply management program.

The reserve should be large enough to handle an expected shortfall in production such as the one the USA saw with corn in 2012 without fully emptying. APAC and the TFU believe that an additional margin should be allowed in the event there is a negative difference between supply and demand in two successive years.

Land set-asides can be used to reduce the total US acreage devoted to crop production and thus total production while allowing farmers to respond to market signals in determining which crops to grow on the remaining land.

In the past, set-asides were criticized for what was called slippage-the reduction of a given percentage of land in production did not result in an equal percentage reduction in production. The primary reason for this is simple, given a choice, farmers take their worst, most environmentally vulnerable acres out of production. But if farmers are to take acres out of production, 
aren't these precisely the acres that one would want farmers to put into a conserving use? In addition, set-asides were criticized by organizations like the American Farm Bureau Federation arguing that reducing US acreage provides other incentives for farmers in other nations to increase their crop acreage. As we saw after the adoption of the 1996 Farm Bill which eliminated set-asides, the US's export competitors increased their productive area both when the USA used set-asides and after the USA eliminated set-asides.

For these reasons, the APAC/TFU program includes a voluntary environmental set-aside in which farmers are given the opportunity to bid acres into a 3-year program. The bids will be evaluated based on a combination of price and the environmental benefits gained by taking the land out of production and putting it into a conserving use. Farmers would be responsible for identifying the environmental practices that would be put in place on the land they offered into the bid process.

Because these set-asides are voluntary, there is no need for farmers to sign up for the APAC/TFU supply management program, with those who offer successful bids benefiting from the voluntary set-aside and all farmers benefitting from the resulting higher prices.

In the past, set-asides had to be contiguous and meet certain other requirements. With an environmental set-aside, the land could include non-contiguous land subject to wind and water erosion as well as buffer strips designed to reduce farm chemical runoff into adjacent waterways. The set-asides could be measured and compliance monitored by remote sensing satellites. The data would be sent to the local Farm Service Agency office for review.

The farmers who bid land into the environmental set-aside benefit from the payments they receive while all farmers benefit from higher prices that result from the reduction in acres. In addition, the public benefits from cleaner air and water.

In the past, set-asides were caricatured as 'paying farmers not to farm.' With this environmental set-aside, farmers are being paid for implementing and maintaining the environmental benefits they provide on the land taken out of production.

Set-asides were also criticized for encouraging our export competitors to increase their production by the amount of land we took out of production. An analysis of the period following the elimination of the previous set-aside program as a part of the 1996 Farm Bill showed that while US farmers increased their planted acres, so did farmers in countries that compete with the USA in agricultural exports (Ray, 2001).

Over the last two decades, crop insurance has become an increasingly important part of the farm program with crop revenue insurance coming to the fore during the last 10 years. Over the years crop insurance has moved from hail insurance to multi-peril yield insurance, to crop revenue insurance. Crop hail insurance is offered by private companies with no government subsidies because the risk was generally limited and random; hail would take out a portion of a field here or there, but the risk of hail over a large area was rare. With the advent of multi-peril crop insurance, government subsidies were required to induce farmers to take out this kind of insurance because it was more expensive than hail insurance. The higher cost was a factor because the range of perils covered was more systemic and could affect a large number of farms over a wide area. Crop revenue insurance came to the fore during a period when crop prices were well above the full cost of production and farmers were unlikely to receive direct government payments from traditional programs. Crop revenue insurance protects farmers against declines in both yield and in-season price changes and presents insurance companies with a systemic risk. Ultimately the government had to subsidize over 60 percent of the crop insurance premium to make it feasible for both farmers and insurance companies. With significant government subsidies, crop insurance became a staple of the farm program over the last decade.

In the long term, however, crop revenue insurance will not work on a regular basis because of the well-documented historical pattern of the production of agricultural crops exceeding the demand for those crops. This imbalance results in prices that fall below the cost of production, even well below the cost of production. Insuring crops at prices that guarantee a loss makes little economic sense.

Revenue insurance only worked well for corn and soybeans when the prices of both crops were above their full cost of production. To maintain the corn price above the full cost of production during the 2007 and 2013 crop years, it took a nearly 500-millionbushels per year increase in corn demand to satisfy the RFS. Once that steady increase in demand ended, the high prices would have not lasted had it not been for a shortfall in production between the 2010 and 2012 crop years.

The appropriate role for crop insurance is to cover the random risk (yield) not the systemic risk (price) and, even then, many farmers will not purchase it without a government subsidy. The APAC/TFU farm program uses crop insurance as a disaster program to cover a yield decline like that seen in 2012. The loan rate would determine the price used in any insurance payment calculation made under the APAC/TFU supply management proposal.

In the past, Congress responded to wide-spread crop production problems with ad hoc disaster programs. But legislators did not respond to localized reductions in crop yields due to weather or disease. By using yield insurance, the APAC/TFU farm program protects farmers who purchase it against localized crop production problems.

One of the questions raised about the APAC/TFU policy proposal concerns WTO compliance. Will the proposed program put the USA out of compliance with its trade obligations? Supply management programs have traditionally been categorized as Blue Box programs and thus trade legal with certain financial limitations.

From the end of WWII until the Uruguay Round of the General Agreement on Trade and Tariffs, agriculture was not subject to the same rules as trade in general products and services. Supply management was seen as way to manage the chronic problem of oversupply in the crop sector while protecting the land and human resources devoted to agricultural production so that future needs can be met. It was also a program-unlike subsidized crop insurance and CCPs-that could be implemented by developing countries working together as in the case of coffee and tea.

It is important to examine the problems that arose as the result of the decision of Congress to lower the loan rate as a part of the 1985 Farm Bill and not raise it after a slight increase in the 2002 Farm Bill-and even then, it was kept well below the full cost of production. The impetus for reducing the loan rate was the belief that higher US loan rates resulted in lower US exports. The argument was that lower loan rates were needed to recapture US export markets. Lowering loan rates did not have the desired result as US corn and wheat exports have languished over the last three decades. Soybean exports were the only crop to see significant increases and that dynamic was due not to US policy, but to a change in policy in China. 
By keeping the loan rate below steadily increasing production costs, Congress had to establish various measures to increase crop prices and revenue-the Counter-Cyclical Program (CCP), the Agricultural Risk Coverage (ARC) programs and the Price Loss Coverage (PLC) program among others. The presence of these programs makes the USA vulnerable to charges of dumping (the selling of commodities into export markets at a price below the full cost of production).

The result of these decisions was a steady increase in the cost of government programs designed to get farm revenue somewhat in line with the steadily increasing cost of producing essential agricultural crops. With these programs, farmers obtained a key component of their net farm income from the government instead of the market. During the 1998-2001 low price period there were instances in which direct government payments to farmers in some states exceeded net farm income, meaning that farmers were using their government payments just to pay operating costs.

With the RFS program, as a part of the Energy Policy Act of 2005 and the Energy Independence and Security Act of 2007, requiring corn-based ethanol production levels, farmers received higher crop prices for nearly a decade, led by corn. It was during this period that crop revenue insurance was implemented. Once the increased demand for ethanol and thus corn leveled off and the carry over levels of corn began to increase, crop prices took a tumble. Beginning with the 2014 crop, the price of corn has been below the full cost of production.

In attempting to make farmers less dependent on the government, farm programs, including the RFS in this category, implemented since the adoption of the 1996 Farm Bill have done just the opposite. They have made farmers more dependent on income from government programs.

Under the APAC/TFU supply management program, farmers would receive the bulk of their income from the marketplace, with the government protecting farmers against weather and diseaserelated crop failures with yield insurance.

This study uses the 'USDA Agricultural Projections to 2026' released in February 2017 (OCE). The USDA projections assume a stable production environment and that the provisions of the [2014 Farm Bill] remain in effect throughout the projection period.... As such, the projections provide a neutral reference scenario that can serve as a point of departure for a discussion of alternative farm-sector outcomes that could result under different domestic or international conditions' (OCE).

The APAC/TFU study uses the APAC POLYSYS computer model to examine the variation away from the USDA baseline projections that would result from a substitution of a set of supply management policies for the 2014 Farm Bill policies embedded in the projections (OCE, 2017). The USDA baseline projections indicate that the average annual net farm income for the 20172026 period would be $\$ 58.0$ billion. The APAC/TFU study results in an average annual net farm income of $\$ 82.8$ billion, a 43 percent increase over the USDA projection. The total government cost over the 2017-2026 period would decline from $\$ 82.7$ billion with the continuation of the current program to $\$ 59.3$ for the APAC/TFU alternative.

The average annual cost of the alternative program of $\$ 5.9$ billion per year is just a little more than the average annual cost of the Direct Payment Program that was eliminated in the 2014 Farm Bill. The ARC and PLC components of the current program are eliminated so those costs are not incurred. The study does not estimate the reduced government outlays for revenue insurance products that are not part of Title ICommodities of the farm bill.

The $\$ 2.3$ billion annual cost savings is a direct result of treating the cause of long periods of low agricultural commodity prices instead of treating the symptoms by backfilling farm income with government payments. Under the APAC/TFU supply management program design, farmers would receive the bulk of their income from the marketplace with a government-subsidized yield insurance program to cover disasters and an environmental acreage reduction program accounting for a small portion of net farm income.

In addition, by reducing revenue insurance costs and eliminating the ARC and PLC, the issues of payment limitations and 'who is a farmer entitled to government payments' become virtual nonissues and small farmers enjoy the same benefit (profitable prices) as large farmers.

Because the US price sets the basis for the world price of most storable commodities, the $\$ 5.9$ billion per year cost of the APAC/ TFU supply management would raise the incomes of farmers around the world and reduce hunger, malnutrition and death because much of the poverty and hunger around the world is concentrated in rural areas or among the displaced rural population in large cities who are economic migrants (Mazoyer et al., 2006, 441-449). Improving farmer incomes will reduce the pressure of the rural to urban migration in developing countries 9 .

By setting the loan rate at 95 percent of the full cost of production, season average prices will remain above that level and eliminate the dumping of US commodities on the world market at prices below the full cost of production and transportation to port.

For people who do not have the money to purchase or the means of obtaining access to an adequate supply of food, the result is malnutrition, stunted growth, disease and even death. They do not eat more food in times of low price, not because they don't want it but because they cannot afford it. Economists call this dynamic 'ineffective demand.' This is the situation that over 800 million people face on a regular basis and is the result of individual States and the international community not stepping up to their obligation to fulfill as a part of the Right to Food.

The world's farmers currently produce enough food to meet the nutritional needs of every man, woman and child in the world. In the short-run, fewer bushels of grain may be used to produce ethanol and to fatten cattle in feedlots, but enough food is produced. And, given the history of agricultural production there is little question that, within a short time, farmers would produce enough basic commodities to meet both human needs and industrial demand and still end up with a surplus.

Author ORCIDs. (DD Harwood D. Schaffer 0000-0001-9249-3639

\section{References}

Committee on Economic, Social and Cultural Rights (1999) CESCR General Comment No. 12: The Right to Adequate Food (Art. 11) Adopted at the Twentieth Session of the Committee on Economic, Social and Cultural Rights, on 12 May 1999 (Contained in Document E/C.12/1999/5), p. 4, No. 15. Available at http://www.refworld.org/pdfid/4538838c11.pdf.

Mazoyer M and Roudart L (2006) A history of world agriculture: from the neolithic age to the current crisis. In Agrarian Crisis and General Crisis.

${ }^{9}$ See Mazoyer and Roudard's (2006) discussion on these issues. 
Chapter 11. New York: Monthly Review Press, pp. 441-494 (translated by James H. Membrez).

Office of the Chief Economist, United States Department of Agriculture (2017) USDA Agricultural Projections to 2026, OCE-2017-1. Available at https://www.usda.gov/oce/commodity/projections /.

Ray DE (2001) Our Export Competitors Harvest 36 Million More Acres Following the 1996 Farm Bill. Available at http://www.agpolicy.org/weekcol/046.html.

Schaffer H (2010) The Assumption of Non-coerciveness and the Total Food Market (PhD diss.). University of Tennessee. Available at http://trace.tennessee.edu/utk_graddiss/847.

Schaffer HD, Hellwinckel C, Ray DE and De La Torre Ugarte DG (2012) An analysis of a Market-Driven Inventory System (MDIS). Available at http:// www.agpolicy.org/publication/NFU-April2012-FinalReport-AsSentToNFU Apr2-2012.pdf.
Schnittker JA (1985) A synthesis. In Gardner BL (ed.) US Agricultural Policy: The 1985 Farm Legislation. Washington, DC: American Enterprise Institute for Public Policy Research, p. 203.

Tweeten L (1985) Commodity market stabilization in farm programs. In Gardner BL (ed.) US Agricultural Policy: The 1985 Farm Legislation. Washington, DC: American Enterprise Institute for Public Policy Research, pp. 83-112.

US House of Representatives (2001) Committee on Agriculture 107th Congress First Session 2001. Current State of the Farm Economy and the Economic Impact of Federal Policy on Agriculture. Serial No. 107-1. Washington, DC: US Government Printing Office.

Wright BD (1985) Farm financial stress, structure of agriculture, and public policy. In Gardner BL (ed.) US Agricultural Policy: The 1985 Farm Legislation. Washington, DC: American Enterprise Institute for Public Policy Research, pp. 257-276. 